\title{
BAHAN AJAR MATAKULIAH BAHASA INDONESIA UNTUK JURUSAN ILMU HUKUM
}

\author{
Suhardi \\ Universitas Tulang Bawang Lampung \\ hardy.adi83@gmail.com
}

\begin{abstract}
ABSTRAK: Artikel ini menguraikan tentang hasil penelitian analisis kebutuhan bahan ajar mata kuliah bahasa indonesi pada jurusan ilmu hukum. Penelitian ini merupakan penelitian kulitatif dengan pendekatan deskriptif. Pengumpulan data dilakukan dengan wawancara dan pengolahan data dilakukan dengan langkah, reduksi, klasifikasi, dan penarikan kesimpulan. Hasil penelitian menunjukkan bahwa bahan ajar matakuliah bahasa indonesia jurusan ilmu hukum mencakup materi tentang (1) membaca dengan analisis untuk mengetahui gagasan atu ide-ide bacaan dan melakukan penilaian bahan bacaan, (3) mendeskripsikan suatu kejadian yang beraspek hukum dalam bentuk tertulis secara objektif, (4) menulis karya ilmiah, (5) menyimak, dan (6) berbicara ilmiah. Penelitian ini juga merekomendasikan penyesuaian silabus mata kuliah Bahasa Indonesia.
\end{abstract}

KATA KUNCI: Bahan Ajar, Bahasa Indonesia, Ilmu Hukum.

\begin{abstract}
This article describes the results of research into the analysis of the needs of Indonesian language teaching materials in the department of law. This research is a qualitative research with descriptive research. Data collection is done by interview and data processing is done by steps, reduction, classification, and conclusion collection. The results of the study show that Indonesian language teaching materials majoring in law include material about (1) reading with analysis to understand thinking or reading ideas and reading reading material, (3) describing cases that have aspects (4) writing scientific papers, (5) listening, and (6) speaking scientifically. Syllabus of Indonesian Language courses.

KEYWORD: Indonesian Language, Legal Studies, Teaching Material.
\end{abstract}

\section{PENDAHULUAN}

Sejak 2012 mata kuliah Bahasa Indonesia dimasukkan ke dalam kelompok Mata Kuliah Dasar Umum (MKDU) sebahai mata kuliah wajib perguruan tinggi dengan landasan upaya meningkatkan kemampuan berbahasa Indonesia. Mahasiswa di perguruan tinggi di tuntut mampu untuk menggunakan bahasa Indonesia dalam berbagai kegiatan akademis. Berbagai tugas dan karya ilmiah harus ditulis dalam ragam bahasa ilmiah.

Pada kenyataanya mahasiswa belum mampu menggunakan bahasa Indonesia dengan benar, bahkan tidak mampu menggunakan bahasa dalam berbagai kegiatan akademis. Mereka terkadang tidak memahami apa yang dibacanya, sehingga setelah membaca buku ilmiah mereka tidak menghasilkan sesuatu apapun. Ini menyebabkan mahasiswa bukan saja mengalami kesulitan kebahasaan tetapi juga kesulitan mengembangkan sikap ilmiah dan buaya ilmiah. Karangan ilmiah bukan saja

ISSN Elektronik : 2614-7718

ISSN Cetak : : 2086-0609 akan baik jika penulis mampu dalam kebahasaan, namun juga di tentukan oleh sikap ilmiah dan budaya ilmiah.

Bahan ajar bahasa Indonesia sering kali hanya bertujuan untuk meningkatkan mahasiswa dalam menulis karya ilmiah. Dalam beberapa bidang ilmu, kemampuan bahasa Indonesia tidak hanya untuk menulis karya ilmiah. Dalam ilmu hukum, mahasiswa di tuntut mampu berbahasa Indonesia dalam kaitannya kemampuan kompetensikompetensi khusus bidang hukum. Kompetensi legal drafting adalah kompetensi menyusun/perancangan peraturan perundang-undangan semisal; pemerintah membuat peraturan perundang-undangan; hakim membuat keputusan pengadilan yang mengikat; swasta membuat ketentuan atau peraturan privat yang mengikat (perjanjian/kontrak, MoU). Kesemuanya ditulis dalam bentuk dokumen tertulis, bebahasa Indonesia yang baik dan tidak ambigu sehingga memiliki sifat kepastian secara hukum. Paling tidak seorang penyusun legal draft harus memiliki 
kompetensi kebahasaan seperti, penggunaan Huruf Kapital, penulisan tanda baca, pemilihan kata dan struktur kalimat agar pernyataan-pernyataan hukum yang dibuat tidak memiliki keambiguan makna.

Upaya pengembangan berbagai pembelajaran guna memberikan perbaikan pembelajaran banyak dilakukan oleh para ahli. Bentuk pengembangan pembelajaran berupa pengembangan model, metode, hingga media pembelajaran. Seluruhnya dilakukan guna meningkatkan pemahaman mahasiswa terhadap materi pembelajaran. Tidak hanya kemamampuan pada ranah kemampuan saja namun pengembangan pembelajaran pada aspek psikomotor dan afektif juga harus muncul pada setiap kegiatan pembelajaran. Untuk mewujudkan hal tersebut di dalam pembelajaran diperlukan adanya inovasi dalam kegiatan pembelajaran.

Tuntutan kurikulum Kerangka Kualifikasi Nasional Indonesia (KKNI) yang ada saat ini berada pada tahapan capaian pembelajaran yang menghasilkan manusia yang memiliki kompetensi sesuai dengan tingkatan pendidikannya. Dalam rangka menghasilkan output tersebut, proses menjadi sangat penting. Bukan hanya mahasiswa yang menjadi andil dalam mencapai tujuan terebut, namun dosen juga memegang peranan yang sangat penting. Dosen dituntut harus mampu menyelenggarakan kegiatan pembelajaran yang sesuai dengan capaian kurikulum.

Buku ajar merupakan salah satu media belajar yang berperan sebagai sumber belajar mahasiswa yang diperlukan untuk mengkontekstualisasikan materi dari matakuliah. Bahan ajar adalah salah satu media belajar yang digunakan dalam pelaksanaan kegiatan perkuliahan dan merupakan salah satu kebutuhan bagi dosen dan mahasiswa. Nasution menyebutkan, fungsi, dan tujuan buku teks pelajaran yaitu: sebagai bahan referensi atau bahan rujukan oleh mahasiswa, bahan evaluasi, alat bantu pendidik dalam melaksanakan kurikulum, salah satu penentu metode atau teknik pengajaran yang akan digunakan pendidik, sarana untuk peningkatan karier dan jabatan. Melalui buku ajar materi dapat disajikan secara riil, oleh sebab itu sajian buku ajar harus mampu menyajikanpada kebutuhan mahasaiswa yang disajikan sesuai dengan tuntutan ketercapaian kurikulum di universitas. Kewajiban dosen untuk menulis buku ajar tertuang di dalam UU No. 12 pasal 12 tahun 2012 tentang Pendidikan Tinggi sebagai sumber belajar guna pengembangan budaya akademik. Pengembangan buku ajar yang diharapkan mampu meningkatkan kualitas proses dan hasil pembelajaran. Dengan demikian jelas bahwa kebutuhan buku ajar menjadi bagian yang penting dalam mencapai hasil belajar yang baik

Penyusunan bahan ajar bahasa Indonesia yang sesuai dengan kebutuhan mahasiswa perlu dilakukan dengan pendekatan maju berkelanjutan. Artinya, bahan ajar harus dikembangkan terus menerus. Pengembangan bahan ajar bahasa Indonesia juga harus memperhatikan kebutuhan akan kompetensi bahasa atas kompetensi khusus pada setiap program studi. Khusus pada jurusan ilmu hukum, mutlak dibutuhkan kemampuan bahasa khusus yang tidak hanya kemampuan dalam hal kaidah bahasa namun juga pemaknaan kebahasaan. Oleh karna itu, dibutuhkan bahan ajar yang sesuai dengan karakter kelimuan dan kebutuhan kebahasaan lulusan. Penelitian ini bertujuan untuk menganalisis kebutuhan materi mata kuliah bahasa Indonesia yang disesuaikan dengan kompetensi lulusan jurusan ilmu hukum.

\section{Ragam Bahasa Peraturan dan Perundang-undangan}

Ragam bahasa peraturan perundangundangan ialah gaya bahasa yang dipergunakan dalam suatu peraturan perundang-undangan, sehingga ia merupakan bahasa Indonesia yang tunduk pada kaidahkaidah bahasa Indonesia, akan tetapi di dalamnya terkandung ciri-ciri khusus yaitu, adanya sifat keresmian, kejelasan makna, dan kelugasan. (Modul 5, Bahasa PerundangUndangan, Diklat Teknis Penyusunan Praturan Perudang-undangan, 2009, hlm. 20) 
1) Sifat keresmian: sifat ini menunjukkan adanya situasi kedinasan, yang menuntut ketaatan dalam penerapan kaidah bahasa, dan ketaatan kepada kaidah bahasa.

2) Sifat kejelasan makna: sifat ini menuntut agar informasi yang disampaikan dinyatakan dengan kalimatkalimat yang memperlihatkan bagianbagian kalimat secara tegas, sehingga kejelasan bagian-bagian kalimat itu akan memudahkan pihak penerima informasi dalam memahami isi atau pesan yang disampaikan. Sifat kejelasan makna ini menuntut agar kalimat-kalimat yang dirumuskan harus menunjukkan dengan jelas mana subyek, predikat, obyek, pelengkap, atau keterangan yang lainnya.

3) Sifat kelugasan: sifat kelugasan ini menuntut agar setiap perumusannya disusun secara wajar, sehingga tidak berkesan berlebihan atau berandai-andai.

Khusus untuk bahasa dalam undangundang, Anton M. Moeliono (1998) mengatakan sebagai berikut: "Bahasa dalam undang-undang, yang dituntut harus jelas, tepat dan tidak boleh bermakna ganda, serta tidak menyapa orang secara pribadi. Selain itu, kalimat dalam Undang-Undang cenderung mirip suatu formula, seperti contoh berikut: "Barangsiapa yang ... dihukum/dipidana dengan hukuman..."

Dengan demikian, dapat dibayangkan betapa pentingnya kedudukan seorang perancang Peraturan Perundang-Undangan (legislatif/ legal drafter) dalam memilih dan menentukan kata dan susunan kalimat yang menghasilkan ungkapan yang tepat sebagaimana dikehendaki oleh pembentuk Undang-Undang (legislator) dan tidak menimbulkan multi tafsir bagi subjek dan objek yang melaksanakan, serta pembaca.

Suatu peraturan perundang-undangan dapat terdiri atas ketentuan-ketentuan yang berupa norma hukum tunggal, dan dapat pula merupakan norma hukum yang berpasangan. Jika norma hukum tersebut merupakan norma hukum tunggal, di dalamnya hanya dirumuskan pedoman bagaimana seseorang harus bertingkah laku di dalam masyarakat; sedangkan jika dirumuskan dalam norma hukum yang berpasangan, maka selain ia merumuskan pedoman bagaimana seseorang harus bertingkah laku dalam masyarakat (yang merupakan norma hukum primer), dirumuskan pula tentang bagaimana tindakan yang harus dilakukan oleh penguasa.

Apabila pedoman tersebut tidak dipenuhi/dilaksanakan dengan adanya sanksi pidana/pemaksa (yang merupakan norma hukum sekunder). Suatu norma dalam peraturan perundang-undangan juga mengandung norma-norma hukum yang bersifat umum, abstrak, dan terus-menerus serta berfungsi menetapkan suruhan (keharusan melakukan perbuatan), larangan (tidak melakukan perbuatan), pembebasan (boleh tidak melakukan perbuatan); atau dapat juga berisi suruhan dan larangan serta mencabut atau menarik kembali wewenang yang diberikan tersebut. Selain itu norma hukum dalam peraturan perundang-undangan yang bersifat umum, abstrak dan terusmenerus dirumuskan dalam kalimat-kalimat yang normatif, jadi tidak deklaratif.

Dalam perumusan suatu peraturan perundang-undangan Montesquieu mengemukakan beberapa batasan sebagai berikut: (Modul 5, Bahasa Perundangundangan)

1) Gaya bahasa hendaknya selain ringkas juga sederhana;

2) Istilah yang dipilih sedapat-dapat bersifat mutlak dan tidak relatif, dengan maksud agar meninggalkan sedikit mungkin timbulnya perbedaan pendapat secara individual;

3) Hendaknya membatasi diri pada riil dan aktual, serta menghindarkan diri dari yang kiasan dan dugaan;

4) Hendaknya tidak halus sehingga memerlukan ketajaman pikiran pembacanya, karena rakyat banyak mempunyai tingkat pemahaman yang sedang-sedang saja; hendaknya tidak untuk latihan logika, melainkan untuk pikiran sederhana yang ada pada ratarata manusia; 
5) Hendaknya tidak merancukan yang pokok dengan yang pengecualian, atau pengubahan, kecuali apabila dianggap mutlak perlu;

6) Hendaknya tidak memancing perdebatan/perbantahan; adalah berbahaya memberikan alasan-alasan yang terlalu rinci karena hal ini dapat membuka pintu pertentangan;

7) Di atas segalanya, hendaknya betul-betul dipertimbangkan apakah mengandung manfaat praktis; hendaknya tidak menggoyahkan dasar-dasar nalar dan keadilan serta kewajaran yang alami; Jeremy Bentham mengemukakan adanya ketidaksempurnaan (imperfections) yang dapat mempengaruhi undang-undang, dan ketidaksempurnaan ini dapat dijadikan asas-asas bagi pembentukan Peraturan Perundang-Undangan.

Ketidaksempurnaan itu dibagi menjadi dua tingkatan, yaitu:

1) Ketidaksempurnaan tingkat pertama disebabkan hal-hal yang meliputi:
a) Arti ganda;
b) Kekaburan;
c) Terlalu luas.

2) Sedangkan ketidaksempurnaan tingkat kedua disebabkan hal-hal meliputi:
a) Ketidaktetapan ungkapan;
b) Ketidaktetapan tentang pentingnya sesuatu;
c) Berlebihan;
d) Terlalu panjang lebar;
e) Membingungkan;
f) Tanpa tanda yang memudahkan pemahaman;
g) Ketidakteraturan.

Menurut Hamid Attamimi (1997, hlm. 14), di dalam merumuskan peraturan perundang-undangan perlu diperhatikan halhal sebagai berikut:

1) Tidak boleh mempunyai arti yang kembar;

2) Harus menggunakan ungkapanungkapan yang jelas (jangan berpuisi);

3) Jangan menggunakan ungkapan yang tidak sempurna;
4) Gaya bahasa harus padat dan sederhana;

5) Penggunaaan istilah yang sudah mutlak/tetap;

6) Jangan mengacaukan yang pokok dengan pengecualian-pengecualian;

7) Hindarkan ketidakteraturan dalam menggunakan kata-kata;

8) Jangan menggunakan kalimat terlalu panjang;

9) Pertimbangkan baik-baik perlu tidaknya peraturan tersebut agar jangan sampai suatu saat hukum itu menjadi korban.

Pada akhirnya, selain pedomanpedoman tersebut di atas, maka hal-hal yang harus diperhatikan bagi seorang penyusun peraturan perundang-undangan adalah kemampuan dalam mengantisipasi atau menafsirkan apa yang mungkin terjadi dengan perumusan-perumusan dalam peraturan perundang-undangan tersebut.

Demikian pula gagasan yang dituangkan dalam peraturan perundangundangan harus dapat mencapai sasaran yang diinginkan. Untuk itu, setiap perancang hendaknya menyadari adanya tiga kebenaran dasar, yaitu (Modul 5, Bahasa Perundangundangan, op. Cit: 4)

1) Bahwa apa yang disampaikan dalam tulisan itu tidak selalu dapat diterima sama atau dengan baik oleh setiap orang. Ada yang menangkap hanya sedikit dari apa yang disampaikan, dan ada yang sama sekali tidak mampu menerima isi tulisan itu. Adapula yang menangkap tulisan itu dengan mudah untuk dapat dimengerti.

2) Bahwa makna yang akan disampaikan itu berada dalam pikiran perancang peraturan perundang-undangan bukan dalam kata atau simbol yang akan digunakannya. Bagaimana cermatnya makna itu dialihkan kepada orang lain tergantung pada keterampilan perancang untuk memilih kata-katanya, dan sejauh mana kecermatan pembaca menginterpretasikan kata-kata itu. Oleh karena itu, perancang harus melihat hal-hal dibalik kata-kata yang digunakan, dan juga harus mempertimbangkan kemampuan 
komunikasi dari mereka yang menerima pesan melalui tulisan itu, dalam hal ini pengguna peraturan perundang-undangan.

3) Bahwa komunikasi selalu tidak sempurna. Hal ini disebabkan oleh kenyataan bahwa kata-kata itu terbatas dan sangat kasar untuk mewakili obyek atau hal yang akan dikomunikasikan. Kata "dapat" dan "boleh" dalam suatu norma dapat menimbulkan persoalan hukum yang berkepanjangan. Arti kata "dapat" menunjukkan adanya kewenangan yang melekat pada seseorang, sedangkan kata "boleh" menunjukkan kewenangan yang tidak melekat pada seseorang. Kata "wajib" dan "harus" kadangkala menimbulkan pula keraguan karena keduanya menyatakan keharusan (gebod) namun berbeda pengenaan sanksinya jika keharusan itu dilanggar. Kita berketetapan bahwa kata "wajib" digunakan untuk menyatakan keharusan, dan kata "harus" digunakan untuk pemenuhan persyaratan. Komunikasi juga tidak sempurna karena para komunikator sendiri memiliki kemampuan yang berbeda-beda untuk mengalihkan pikirannya. Ada orang yang dengan mudah mengerti suatu kata yang diterima olehnya, namun ada pula yang sebaliknya. Ada orang yang dengan mudah mengartikan kata-kata "kepentingan umum", "stabilitas nasional", "kerawanan", "keadaan darurat", "penyesuaian", dan "keadilan", dan lain-lain.

\section{Teori Bahan Pembelajaran}

Bahan pembelajaran merupakan salah satu jenis bahan pembelajaran yang digunakan oleh dosen. Untuk mengembangkan bahan pembelajaran yang efektif menurut Gerlach dan Ely (dalam Karim, 2000, hlm. 86) harus memenuhi syarat- syarat: (1) ketepatan kognisi (cognitive appropriatness); (2) tingkat berpikir (level of sophistication); (3) biaya; (4) ketersediaan bahan (availability); dan (5) mutu teknis (tehcnical quality).
Lima komponen yang diajukan oleh Gerlach dan Ely merupakan satu kesatuan yang tidak dapat dipisahkan. Jika dalam pengembangan bahan pembelajaran salah satu komponennya tidak terpenuhi maka kemungkinan hasil produk bahan pembelajaran tidak akan maksimal, misalnya komponen biaya tidak terpenuhi maka proses produksi, proses uji validitas, dan pemenuhan kebutuhan akan bahan untuk penyusunan produk juga akan bermasalah.

Sedangkan dalam pengembangan Perangkat pembelajaran, Dick and Carey (2001, hlm. 52), mengajukan hal-hal berikut untuk diperhatikan, yakni: (1) memperhatikan motivasi belajar yang diinginkan, (2) kesesuaian materi yang diberikan, (3) mengikuti suatu urutan yang benar, (4) berisikan informasi yang dibutuhkan, dan (5) adanya latihan praktek, (6) dapat memberikan umpan balik, (7) tersedia tes yang sesuai dengan materi yang diberikan, (8) tersedia petunjuk untuk tindak lanjut ataupun kemajuan umum pembelajaran (9) tersedia petunjuk bagi peserta didik untuk tahap-tahap aktivitas yang dilakukan, dan (10) dapat diingat dan ditransfer.

Berdasarkan beberapa pendapat para ahli tersebut menunjukkan bahwa persepsi masing-masing para ahli tentang suatu pengembangan bervariasi. Adanya variasi persepsi tidak berarti terjadi perbedaan yang signifikan, sebab semua ahli mendasari pendapatnya berdasarkan pada hasil penelitian masing-masing.

Pengembangan bahan pembelajaran merupakan bagian dari upaya memperbaharui kualitas pembelajaran dan salah satu alternatif untuk meningkatkan hasil belajar mahasiswa (output). Selain cara belajar, bahan pembelajaran yang baik juga dapat meningkatkan hasil belajar mahasiswa. Antara penerapan model- model pembelajaran dengan pengembangan bahan pembelajaran berupa bahan pembelajaran sebenarnya mempunyai tujuan yang sama, yaitu untuk mempermudah penyampaian materi perkuliahan. Perbedaan antara 
keduannya adalah penerapan model-model pembelajaran merupakan langkah terorganisir untuk menyampaikan materi pelajaran secara langsung, sedangkan bahan pembelajaran merupakan sarana untuk mengorganisir materi perkuliahan dan menyampaikannya secara tidak langsung. Dengan bahan pembelajaran yang berkualitas dan mudah dimengerti, dapat menjadikan mahasiswa lebih mudah menyerap materi.

Merujuk pada kenyataan adanya perubahan setiap ilmu, maka pengembangan suatu produk ilmu pengetahuan menjadi sebuah pilihan untuk memperbaharui pengetahuan yang tidak sesuai lagi dengan kondisi dan fakta yang ada Miarso (2004). Salah satunya adalah bahan pembelajaran yang diperuntukan bagi mahasiswa khususnya pada Jurusan Ilmu Hukum.

Dosen sebagai pekerja profesional diharapkan melaksanakan proses belajar dan pembelajaran yang berkualitas, sedangkan untuk mencapai kualitas proses belajar mengajar yang memadai, tentunya harus ditunjang oleh komponen-komponen lain termasuk bahan pembelajaran sebagai satu sistem dalam kurikulum. Apabila ternyata kualitas proses belajar mengajar diketahui tidak mendukung tercapainya tujuan pendidikan, maka salah satu komponen kurikulum yang perlu ditinjau adalah bahan atau perangkat pembelajaran.

Bahan pembelajaran atau lebih dikenal dengan sebutan buku ajar telah disediakan oleh dosen, pemerintah dan pihak swasta serta diedarkan secara nasional untuk semua jenis dan tingkatan sekolah dan perguruan tinggi. Penggunaan buku- buku tersebut sejauh mungkin diarahkan guna dapat menunjang pelaksanaan pembelajaran. Dalam hal ini satuan acara pembelajaran yang disiapkan oleh dosen merupakan rambu-rambu dan acuan dalam proses belajar dan pembelajaran dan selalu dilengkapi dengan bahan pembelajaran.

Berdasarkan pendapat para ahli di atas, diketahui bahwa bahan ajar mampu berperan dalam memberikan landasan yang baik untuk membangun kegiatan pembelajaran tingkat tinggi yang menarik dan menuntut tata cara berpikir kritis serta kegiatan mental tingkat tinggi lainnya. Oleh karena itu, bahan ajar yang digunakan oleh mahasiswa sebagai penunjang proses pembelajaran hendaknya bahan ajar yang berkualitas.

Penelitian ini adalah bagian dari penelitian Pengembangan Bahan Ajar Mata Kuliah Mata Kuliah Bahasa Indonesia pada jurusan ilmu hukum. Didasari model pengembangan Dick and Carey penelitian ini merupakan tahapan awal dari keseluruhan penelitian yang akan dilaksanakan yaitu berupa Analisis kebutuhan. Tujuan pembelajaran dapat diperoleh dari serangkaian tujuan pembelajaran yang ditemukan dari analisis kebutuhan, dari kesulitan-kesulitan mahasiswa dalam praktek pembelajaran, dari analisis yang dilakukan oleh orang-orang yang bekerja dalam bidang, atau beberapa keperluan untuk pembelajaran yang aktual.

\section{Modul Mata Kuliah Bahasa Indonesia Dikti}

Tahun 2013 Kementrian Pendidikan dan Kebudayaan merubah kurikulum mulai dari pendidikan dasar sampai pendidikan tinggi. Sesuai dengan Undang-undang No.12 Tahun 2012. Perguruan tinggi memiliki otonomi dalam hal menyusun kurikulum didasarkan rambu-rambu yang sama guna mencapai hasil yang optimal.

Didasari tujuan Pendidikan Tinggi dalam UU No 12 tahun 2012 yaitu menjadikan manusia yang beriman dan bertakwa kepada Tuhan Yang Maha Esa dan berakhlak mulia, sehat, berilmu cakap, kreatif, mandiri, terampil, kompeten, dan berbudaya untuk kepentingan bangsa, maka selutuh mahasiswa harus mengikuti mata kuliah dasar umum yang disingkat (MKDU). Mata kuliah wajib yang dinyatakan dalam UU No.12 Tahun 2012 antara lain, Agama, Pancasila, Kewarganegaraan dan Bahasa Indonesia.

Mata Kuliah Bahasa Indonesia merupakan pelajaran mengembangakan 
kemampuan mahasaiswa dalam berbahasa indonesia dengan baik dan benar, karena matakuliah bahasa indonesia dapat dijadikan ukuran nasionalisme seseorang sebagai bangsa Indonesia, serta mengembangkan kemampuan mahasiswa dalam mengorganisir ide-ide atau konsep-konsep untuk dikomunikasikan kepada pihak lain sehingga terjalin interaksi antar ide yang berkesinambungan dan menghasilkan proses transfer ilm dan pengetahuan yang berjalan efektif.

- Dirjen Dikti Melalui Direktorat Pembelajaran dan Kemahasiswaan menerbitkan Modul "Materi Kuliah Matakuliah Bahasa Indonesia" dengan kompetensi sebagai berikut:

- Meningkatkan kemampuan pemahaman atas fungsi bahasa Indonesia baik lisan maupun tulisan

- Meningkatkan kemampuan memahami ragam bahasa dan aneka laras bahasa Indonesia baik lisan maupun tulisan

- Meningkatkan kemampuan keterampilan menulis dengan ejaan dan tanda baca yang benar.

- Meningkatkan kemampuan mahasiswa dalam menyampaikan pikirannya dalam bentuk kalimat.

- Meningkatkan kemampuan mahasiswa dalam menyampaikan pikirannya dalam bentuk paragraf.

- Meningkatkan pemahaman mahasiswa atas jenis tulisan dalam Bahasa Indonesia tulis dan dapat menerapkan dan menghasilkan jenis-jenis tulisan tersebut.

- Meningkatkan kemampuan mahasiswa mengenai ciri dan perbedaan ringkasan, abstrak, sintesis, dan cara menerapkannya dalam berbagai keperluan.

- Meningkatkan kemampuan mahasiswa mengenai konsep kutipan dan sistem rujukan serta cara menerapkannya dalam berbagai keperluan.

- Meningkatkan kemampuan mahasisa dalam menyusun langkah-langkah penulisan ilmiah.
Berdasarkan tabel kompetensi dan indikator keberhasilan diatas, belum memperlihatkan kompetensi bahasa indonesia untuk bidang hukum. Kompetensi utama masih seputar kemampuan mahasiswa dalam membuat karya tulis. Yang dalam bahasa indonesia hal tersebut masuk kedalam tatanan struktur (Sintaksis). Dalam kaitanya dengan prinsip bahasa hukum, materi kuilah tersebut belum menyentuh makna bahasa (Semantik) yang menyangkut kelugasan dan kesatuan makna.

\section{METODE}

Penelitian ini dilakukan di UTB Lampung, Jln. Gajah Mada No.34 Bandar Lampung karena memiliki Program Studi Ilmu Hukum yang sesuai dengan kajian dalam penelitian ini, pengambilan data dan wawancara dilakukan pada bulan Januari 2017.

Metode yang digunakan dalam penelitian ini adalah pendekatan kualitatif dengan metode analisis deskriptif, yakni sebuah desain yang memberi kemudahan bagi peneliti untuk merekam, memantau dan mengikuti proses suatu peristiwa atau kegiatan sebuah organisasi sebagaimana adanya dalam suatu kurung waktu tertentu dan selanjutnya diinterpretasikan untuk menjawab masalah penelitian. Sebagaimana dijelaskan oleh Locke, Spriduso dan Silferman dalam Creswell (1994:147): "Qualitative research is interpretative research. As such the blases, values and judgement of the researches become stated explicity in the research report. Such openness is considered to be useful and posetive"

Sedangkan, metode analisis deskriptif yang dikemukakan oleh Sugiono (2011, hlm. 79) "adalah metode yang digunakan untuk menggambarkan atau menganalisis suatu hasil penelitian tetapi tidak digunakan untuk membuat kesimpulan yang lebih luas".

Digunakannya metode deskriptif dengan pendekatan kualitatif, dimaksudkan untuk membuat deskripsi, gambaran secara sistematis, faktual, dan akurat mengenai suatu objek, suatu set kondisi pada masa 
sekarang serta hubungan antar fenomena yang diselidiki.

Pendekatan kualitatif diyakini mampu mengarahkan pencarian-pencarian konsep baru dari kombinasi antara perspektif yang diteliti dan perspektif peneliti sendiri, melalui pendekatan yang mengedepankan kriteria empirik sensual dan empiric logic, sebagaimana halnya paradigma kualitatif modern sehingga akan lahir proposisi hipotetik baru melalui interpretasi proses dan makna dari suatu fenomena yang selanjutnya digunakan untuk membangun prediksi dan memberikan penjelasan terhadap fenomena yang diteliti.

Informan dalam penelitian adalah orang atau pelaku yang benar-benar tahu dan menguasai masalah, serta terlibat langsung dengan masalah penelitian. Dengan menggunakan metode penelitian kualitatif, maka peneliti sangat erat kaitannya dengan faktor-faktor kontekstual, jadi dalam hal ini sampling dijaring sebanyak mungkin informasi dari berbagai sumber. Maksud kedua dari informan adalah untuk mengali informasi yang menjadi dasar dan rancangan teori yang dibangun.

Pemilihan informan sebagai sumber data dalam penelitian ini adalah berdasarkan pada asas subyek yang menguasai permasalahan, memiliki data, dan bersedia memberikan imformasi lengkap dan akurat. Informan yang bertindak sebagai sumber data dan informasi harus memenuhi syarat. informan ditentukan dengan teknik snowball sampling, yakni proses penentuan informan berdasarkan informan sebelumnya tanpa menentukan jumlahnya secara pasti dengan menggali informasi terkait topik penelitian yang diperlukan. Pencarian informan akan dihentikan setelah informasi penelitian dianggap sudah memadai. yang akan menjadi informan narasumber (key informan) dalam penelitian ini adalah Dosen Mata Kuliah Legal Drafting, Metodologi Penelitian, Dekan dan Kaprodi serta Praktisi Hukum.

Pengumpulan data dalam penelitian ini menggunakan teknik Wawancara Mendalam dan Studi Kepustakaan. Instrumen Penelitian yang digunakan dalam penelitian ini adalah (1) Pedoman wawancara terhadap dosen untuk memperoleh informasi tentang kompetensi kebahasaan yang dibutuhkan oleh lulusan Program Studi Ilmu Hukum Fakultas Hukum UTB Lampung. (2) Angket untuk mengumpulkan data persepsi dosen matakuliah Legal Drafting, dosen mata kuliah metodologi penelitian, kaprodi dan dekan serta praktisi tentang materi Mata Kuliah Bahasa Indonesia Fakultas Hukum dan Kompetensi kebahasaan lulusan ilmu hukum.

\section{HASIL DAN PEMBAHASAN}

\section{Kompetensi Bahasa Indonesia Mahasiswa Ilmu Hukum}

Deskripsi data yang di lakukan terhadap hasil wawancara menunjukkan bahwa keempat keterampilan bahasa sangat dibutuhkan dalam menunjang kompetensi ilmu hukum. Berikut adalah deskripsi hasil wawancara informan.

berdasarkan data dikumpulkan maka diperoleh hasil reduksi data penelitian kebutuhan bahan ajar mata kuliah bahasa Indonesia untuk jurusan ilmu hukum sebagai berikut.

\section{Keterampilan Membaca}

Membaca adalah keterampilan reseptif bahasa tulis, ketermpilan membaca dapt dikembangkan secara tersendiri, terpisah dari keterampilan mendengarkan dan berbicara.

Keterampilan mikro yang terkait dengan proses membaca antara lain adalah:

- Mengenal sistem tulisan yang dibaca

- Mengenal kosakata

- Menentukan kata-kata kunci yang mengidentifikasikan topik dan gagasan utama

- Menentukan makna kata-kata, termasuk kosakata sulit, dari konteks tertulis

- Mengenal kelas gramatikal, kata benda, kata sifat dan sebagainya.

- Menentukan konstituen-konstituen dalam kalimat. Seperti subjek predikat, objek, preposisi dan lain-lain. 
- Mengenal bentuk-bentuk dasar sintaksis

- Merekrontuksi dan menyimpulkan situasi, tujuan-tujuan, dan partisipan

- Menggunakan perangkat kohesif leksikal dan gramatikal guna menarik kesimpulankesimpulan

- Menggunakan pengetahuan dan perangkatperangkat kohesif leksikal dan gramatikal untuk memahami topik utama atau informasi utama

- Membedakan ide utama dari detail-detail yang disajikan

- Menggunakan strategi membaca yang berbeda tujuan-tujuan membaca yang berbeda, seperti skimming untuk mencari ide-ide utama atau melakukan studi secara mendalam. (Cahyani, 2009)

Mahasiswa diharapkan mampu membaca dengan analisis untuk mengetahui gagasan atu ide-ide bacaan dan melakukan penilaian bahan bacaan, seperti yang disampaikan narasumber Ibu Fitri bahwa mahasiswa hukum dan lulusan harus mampu membaca kalimat-kalimat hukum dengan objektif, mengesampingkan kesimpulan pribadi dan mampu mengaitkan kalimat satu dengan kalimat lain dalam satu dokumen hukum. Sebagai seorang dosen Ibu Fitri juga memberikan tanggapan mengenai kemampuan mahasiswa mempelajari teori teori hukum kaitannya dalam penyusunan tugas akhir kuliah, beliau mengharapkan seorang mahasiswa harus mampu membuat tinjauan teoritis tentang hukum, mahasiswa dan lulusan harus memiliki bekal teori yang cukup, hal ini didapat lewat seringnya membaca buku-buku hukum.

Hal ini dapat disimpulkan bahwa pembelajaran bahasa indonesia khususnya pada keterampilan membaca pada mahasiswa adalah pembelajaran membaca kritis. Membaca kritis adalah membaca yang bertujuan untuk mengetahui fakta-fakta yang terdapat dalam bacaan kemudian memberikan penilaian terhadap fakta itu. Agustina (2008, hlm. 124). Pembaca tidak hanya sekedar menyerap masalah yang ada, tetapi ia bersama penulis berpikir tentang masalah yang dibahas. Membaca kritis berarti harus membaca secara analisis dan dengan penilaian.

Dalam membaca kritis pembaca harus terbuka terhadap gagasan orang lain. Pembaca harus mengikuti pikiran penulis secara tepat, akurat dan kritis. Akurat artinya dalam hubungan relevansi, membedakan yang relevan dan yang tidak relevan atau tidak benar. Kritis berarti menerima pikiran penulis dengan dasar yang baik, logis, benar atau menurut realitas. Karena dalam membaca kritis membaca akan menganalisis, membandingkan dan menilai.

Kegiatan Dalam Membaca Kritis Ada tiga kegiatan yang terdapat dalam membaca kritis

\section{Membaca Dengan Berpikir}

Membaca hendaknya memikirkan persoalan-persoalan atau fakta-fakta yang ditampilkan dalam bacaan. Pembaca memikirkan maksud dan tujuan penulis mengemukakan fakta-fakta tersebut. Tujuan pembaca dengan cara berpikir ini supaya pembaca dapat menentukan batasab-batasan dari persoalan-persoalan atau fakta-fakta yang dikemukakan oleh pengarang

\section{Membaca Dengan Menganalisis}

Analisis merupakan kunci membaca kritis. Dengan menganalisis pembaca dapat mengetahui apakah gagasan atau fakta-fakta yang dikemukakan pengarang sungguh di sokong oleh detail-detail yang diberikannya atau tidak. Pembaca selanjutnya dengan cara itu akan dapat memisah-misahkan mana detail-detail yang penting, mana detail yang cocok dan detail yang tidak cocok.

\section{Membaca Dengan Penilaian}

Tugas pembaca kritis adalah menilai fakta atau pernyataan yang dapat menyokong gagasan pokok yang dikemukakan. Pembaca harus sanggup menentukan apakah fakta yang dibacanya ada hubungannya satu dengan yang lainnya atau mungkin pembaca nenemukan dua atau lebih fakta yang seharusnya dipandang sebagai fakta yang terpisah. Akhirnya pembaca menentukan penilaian terhadap fakta-fakta yang disajikan 
FON : Jurnal Pendidikan Bahasa dan Sastra Indonesia

Volume 15 Nomor 2 Tahun 2019

oleh penulis. Bahan-bahan yang dibaca secara kritis meliputi hal-hal sebagai berikut.

- Esai

- Biografi dan autografi

- Drama

- Laporan-laporan yang bertentangan atau kesimpulan-kesimpulan yang berbeda dalam lapangan sejarah, ekonomi, hukum dan politik

- Peristiwa-peristiwa yang dijumpai dalam koran, majalah, propaganda dan lainlain.

\section{Keterampilan Menulis}

Menulis merupakan kegiatan untuk mengekspresikan pikiran, perasaan, dan gagasan seseorang dalam bentuk kata kata atau tulisan. Hasil sebuah tulisan yang dibuatpun juga terpengaruh dari kemampuan serta pengalaman mendengarkan dan membaca dari penulis. Menulis adalah salah satu keterampilan bahasa yang produktif dan ekspresif yang digunakan untuk berkomunikasi secara langsung dan tidak secara tatap muka dengan pihak lain (Tarigan, 2008).

Berdasarkan hasil wawancara dengan narasumber didapat pernyataan bahwa (1) Mahasiswa atau lulusan jurusan ilmu hukum diharapkan mampu mendeskripsikan suatu kejadian yang beraspek hukum dalam bentuk tertulis secara objektif.

Mahasiswa atau lulusan jurusan ilmu hukum diharapkan mampu dalam menulis karya ilmiah seperti makalah, laporan ilmiah maupun skripsi menggunakan bahasa indonesia yang baik dan benar. Secara garis besar, mahasiswa diharapkan memiliki kompetensi dasar dalam menulis. Kompetensi ini dijabarkan berikut.

- Mahasiswa memahami konsep, jenis, dan komponen tulisan (ragam ilmiah dan populer).

- Mahasiswa memahami asas-asas dan proses menulis.

- Mahasiswa memahami proses pengolahan bahan dan organisasi tulisan.4.2.1. Kompetensi Bahasa Indonesia Mahasiswa Ilmu Hukum

- Mahasiswa memahami kaidah-kaidah penulisan berbahasa Indonesia.

- Mahasiswa terampil menulis beragam tulisan.

Khusus pada mahasiswa jurusan ilmu hukum berdasarkan hasil pengolahan data perlu ada penekanan pada kemampuan menulis deskriptif dan naratif dimana penulisan menekankan pada pendekatan faktual.

Tulisan deskripsi dimaksudkan untuk menciptakan sebuah pengalaman pada diri pembaca dan memberi identitas, atau informasi mengenai objek tertentu sehingga pembaca dapat mengenalinya bila bertemu atau berhadapan dengan obyek tadi. Penulis perlu mengambil sikap tertentu untuk dapat memperoleh gambaran tentang suatu obyek penulisan. Oleh karena itu, penulis perlu menggunakan pendekatan dalam menulis deskripsi. Menurut Finoza (2002, hlm. 190191) pendekatan dalam menulis deskripsi adalah pendekatan realistik dan pendekatan impresionostis.

Tujuan menulis karangan naratif yaitu menceritakan, memaparkan atau melaporkan suatu kejadian atau pengalaman seseorang sehingga pembaca memperoleh informasi yang jelas. (Tim pengajar subjek, 2009, hlm. 93)

Ciri-ciri karangan naratif menurut Keraf (2000, hlm. 136) yaitu :

- Menonjolkan unsur perbuatan atau tindakan.

- Dirangakai dalam urutan waktu.

- Berusaha menjawab pertanyaan "apa yang terjadi”.

- Ada konflik.

\section{Keterampilan Menyimak/mendengarkan}

Menyimak adalah mendengar secara khusus dan terpusat pada objek yang disimak (panduan bahasa dan sastra Indonesia, Natasasmita Hanapi, Drs., 1995, hlm. 18)

Menyimak dapat didefinisikan suatu aktivitas yang mencakup kegiatan mendengar dan bunyi bahasa, 
FON : Jurnal Pendidikan Bahasa dan Sastra Indonesia

Volume 15 Nomor 2 Tahun 2019

mengidentifikasi, menilik, dan mereaksi atas makna yang terkandung dalam bahan simakan. (Djago Tarigan; 1991, hlm. 4).

\section{Tujuan Menyimak}

Tujuan utama menyimak adalah untuk menangkap dan memahami pesan, ide serta gagasan yang terdapat pada materi atau bahasa simakan. Dengan demikian tujuan menyimak dapat dijabarkan sebagai berikut:

- Menyimak memperoleh fakta atau mendapatkan fakta

- Untuk menganalisis fakta

- Untuk mengevaluasi fakta

- Untuk mendapatkan inspirasi

- Untuk mendapatkan hiburan atau menghibur diri

Pada hasil pengolahan data didapat pernyataan sebagai berikut. “..Karena saat kita menyimak, kita dapat memperoleh informasi dan memahami makna dari informasi tersebut, sehingga memudahkannya untuk memecahkan suatu masalah dan mencari jalan keluar.." berdasarkan hal itu maka mahasiswa diharapkan memiliki keterampilan menyimak. Terdapat dua macam menyimak, yaitu: 1) menyimak ekstensif, menyimak mengenai hal-hal yang lebih umum dan lebih bebas terhadap suatu ujaran; 2) Menyimak intensif, merupakan kebalikan dari menyimak ekstensif. Menyimak intensif lebih diarahkan pada suatu kegiatan yang lebih diawasi, dikontrol terhadap hal tertentu. (Tarigan, 1994)

\section{Keterampilan Berbicara}

Dari hasil pengumpulan data didapat point penting tentang keterampilan berbicara yang diharapkan dimiliki oleh mahasiswa adalah bahwa Mahasiswa saat ini minim dalam penguasaan kemampuan berbicara, terlihat dalam hal kemampuan menjawab pertanyaan. Pertanyaan yang sering lontarkan dalam perkuliahan sering kali di jawab dengan singkat, mahasiswa belum mampu menjawab dengan argumen-argumen yang terstruktur.

Pengertian berbicara dapat dibedakan atas dua macam, yaitu pengertian berbicara secara sempit dan secara luas. Pengertian berbicara secara sempit adalah kegiatan mengucapkan bunyi-bunyi bahasa. Selanjutnya, pengertian berbicara secara luas adalah kegiatan mengucapkan bunyi-bunyi bahasa untuk menyampaikan pesan, mengekspresikan perasaan, dan menyatakan pikiran.

Agar dapat tercapai tujuan dan maksud berbicara maka seseorang yang ingin terampil berbicara perlu memiliki empat aspek pendukung, yaitu (1) keterampilan sosial (social skills) adalah keterampilan untuk berperanan secara aktif dan efektif di dalam kehidupan bermasyarakat, (2) keterampilan semantik (semantic skills) adalah keterampilan untuk menggunakan kata-kata secara tepat, (3) keterampilan fonetik (phonetic skills) adalah keterampilan untuk membentuk unsur-unsur bunyi bahasa secara akurat, dan (4) keterampilan vokal (vocal skills) adalah keterampilan untuk menciptakan efek emosional dengan suaranya kepada pendengar atau mitratutur.

\section{Materi Bahan Ajar Mata Kuliah Bahasa Indonesia Jurusan Ilmu Hukum}

Dari hasil klasifikasi data pada subbab sebelumnya memandingkan teoriteori yang ada maka dapat diuraikan materi yang dibutuhkan dalam bahan ajar matakuliah bahasa indonesia jurusan ilmu hukum sebagai berikut.

\begin{tabular}{cccc}
\hline o Ketrampilan & Temuan Penelitian (kemampuan yang diharapkan) & Materi bahan ajar \\
& & \\
\hline Kebahasaan & Mahasiswa membaca dengan analisis untuk & Membaca Kritis \\
& mengetahui gagasan atu ide-ide bacaan dan melakukan & 1. & Membaca Dengan Berpikir \\
& penilaian bahan bacaan & 2. & Membaca Dengan Menganalisis \\
& & 3. & Membaca Dengan Penilaian
\end{tabular}


FON : Jurnal Pendidikan Bahasa dan Sastra Indonesia

Volume 15 Nomor 2 Tahun 2019

\begin{tabular}{|c|c|c|c|}
\hline $\begin{array}{l}\text { Keterampilan } \\
\text { Menulis }\end{array}$ & $\begin{array}{l}\bullet \text { Mahasiswa diharapkan mampu } \\
\text { mendeskripsikan suatu kejadian yang beraspek hukum } \\
\text { dalam bentuk tertulis secara objektif. } \\
\bullet \quad \text { Mahasiswa atau lulusan jurusan } \\
\text { ilmu hukum diharapkan mampu dalam menulis karya } \\
\text { ilmiah }\end{array}$ & $\begin{array}{ll}- & \mathrm{P} \\
1 . & \mathrm{D} \\
2 . & \mathrm{E} \\
3 . & \mathrm{K} \\
4 . & \mathrm{P} \\
5 . & \mathrm{J} \\
6 . & \mathrm{N} \\
- & \mathrm{P}\end{array}$ & $\begin{array}{l}\text { Penunjang Keterampilan Menulis } \\
\text { Diksi } \\
\text { EYD } \\
\text { Kalimat dan Kalimat Efektif } \\
\text { Paragraf } \\
\text { Jenis Tulisan/karangan } \\
\text { Menulis deskriptif dan Naratif } \\
\text { Penulisan karya ilmiah }\end{array}$ \\
\hline $\begin{array}{l}\text { Keterampilan } \\
\text { menyimak }\end{array}$ & $\begin{array}{l}\text { Mahasiswa diharapkan mampu menangkap } \\
\text { dan memahami pesan, ide serta gagasan yang terdapat } \\
\text { pada materi atau bahasa simakan. }\end{array}$ & $\begin{array}{ll}- & \mathrm{P} \\
- & \mathrm{N} \\
- & \mathrm{N} \\
- & \mathrm{N}\end{array}$ & $\begin{array}{l}\text { Pengertian dan jenis menyimak } \\
\text { Menyimak ekstensif } \\
\text { Menyimak intensif } \\
\text { Melatih daya simak }\end{array}$ \\
\hline $\begin{array}{l}\text { Keterampilan } \\
\text { Berbicara }\end{array}$ & $\begin{array}{l}\text { Mahasiswa diharapkan mampu mengucapkan } \\
\text { bunyi-bunyi artikulasi atau kata-kata untuk } \\
\text { mengekspresikan, menyatakan serta mengungkapkan } \\
\text { pendapat atau pikiran dan perasaan kepada seseorang } \\
\text { atau kelompok secara lisan, baik secara berhadapan } \\
\text { ataupun dengan jarak jauh. }\end{array}$ & $\begin{array}{l}\text { - Diskusi } \\
\text { - Pidato } \\
\text { - Ceramah } \\
\text { - Wawanca }\end{array}$ & ara \\
\hline
\end{tabular}

\section{KESIMPULAN}

Berdasarkan hasil penelitian di atas dapat disimpulkan bahwa materi ajar Matakuliah Bahasa Indonesia pada jurusan Ilmu Hukum masih perlu di sesuaikan dengan kompetensi Jurusan Ilmu Hukum. Perbaikan mendasar khusus dalam hal materi, selain mempertimbangkan kompetensi hukum juga mempertimbangkan tingkat kesulitan/ ke-dalaman materi.

Berdasarkan hasil penelitian, maka peneliti mencoba memberikan beberapa saran atau rekomendasi sebagai berikut:

- Penyesuaian silabus matakuliah Bahasa Indonesia pada Program Studi Ilmu Hukum Universitas Tulang Bawang

- Penyediaan Buku Teks Bahasa Indonesia yang relevan dengan rekomendasi materi bahan ajar dalam penelitian.

- Merekomendasikan penelitian lanjutan mengenai metode pembelajaran dan penyusunan buku ajar matakuliah Bahasa Indonesia Jurusan Ilmu Hukum.

\section{DAFTAR PUSTAKA}

Anton, M. Moeliono, dkk. (1998). Tata Bahasa Baku Bahasa Indonesia Edisi Ketiga. Jakarta: Balai Pustaka.
Attamimi A. Hamid, (1997). Materi Muatan Peraturan Perundang-Undangan, Majalah Hukum dan Pembangunan, Jakarta

Creswell, J. W. (1994). Research Design Qualitative and Quantitative Approaches. Sage Publications. London.

Dick, Walter and Carey, Lou. (2001). The Sistemetic Design of Instruction. Illionois: Scott, Foresman and Company.

Karim, M. (2000). Pemilihan Bahan Pengajaran. Jakarta: Penlok P3G.

Miarso, Yusuf Hadi. (2004). Menyemai Benih Teknologi Pendidikan. Jakarta: Prenada Media.

Miles, B.B., dan A.M. Huberman, (1992), Analisa Data Kualitatif, Jakarta: UI Press Modul 5, Bahasa PerundangUndangan, Diklat Teknis Penyusunan Praturan Perudangundangan (Legal Drafting), Tahun 2009.

Prastowo, Andi. (2012). Panduan Kreatif Membuat Bahan Ajar Inovatif. Jogjakarta: DIVA Press

Sugiyono. (2011). Metode Penelitian Kuantitatif, Kualitatif dan $R \& D$. Bandung: Afabeta

Kemendikbud. (2012). UU No. 12 pasal 12 tahun 2012 tentang Pendidikan Tinggi 